\title{
European History and the Future of Legal Freedoms
}

Diversity in the European Union can be showcased with the help of the famous futurist Patrick Dixon, who identifies the main challenges between European tribalism versus a common voice: "Disputes over budget deficits, overspending, beef, lamb, asylum seekers, chocolate, Iraq and so on are not just superficial. They often hide very long, historical issues and profound resentments" (Dixon, n.d.). The latest keywords with symbolic significance in the EU bear rather negative connotations - Crimea, Syriza and Pegida are just a few examples. Furthermore, the hectic times are shadowed by unpopular political decisions related to an increasing number of refugees, the endless epics on Greek debts, and, of course, protracted war in Ukraine. Today's Europe is approaching many crossroads in the mist. The German-led doctrine of austerity has been severely criticized by many and even though the darkest hour of recession is claimed to be over, the common vision of European future is far from being rock steady.

The given volume of the Baltic Journal of European Studies (BJES) is composed of contributions by scholars from Estonia, Finland, Greece, Lithuania, Poland, and the Czech Republic - countries which are different in size and political history, yet share the same European values that also become apparent in the articles presented. We introduce the volume with articles that embrace the European perspectives in general: better solutions for fiscal policy and the qualitative difference between coordinated marked versus liberal market approach; technology transfer within the European Union and digital cooperation between the Member States; and legal problems related to the EU asylum fingerprint database.

Some of the articles highlight the indisputable reality of the ageing Europe: one of the contributors analyzes the dilemmas of the upcoming EU Succession Regulation, another author is concerned about associational solidarity to elderly parents. The basic principle of equality is one of the foundations of a citizens' Europe; therefore, the inclusion of the article searching for common threads in anti-EU attitudes, in comparison with hostility against sexual minorities, is certainly grounded.

The well-known Latin expression veritas vos liberabit ('the truth shall set you free') succinctly illustrates the article about the right to know the truth 
through the example of access to the archives related to communist crimes once committed in Central and Eastern Europe. Rule of law can be straightforwardly perceptible only in a perfect society; thus, the contribution which discusses the consequences of maladministration and nullity of defective acts demonstrates the complexity of the aforementioned maxim in actual life situations. The current volume concludes with the article on participatory democracy, that is, the effectiveness of referenda in three EU Member States.

BJES has always been an observer of political, economic and social trends in Europe and while Stefan Klein (2004) may eulogize over the power of unpredictability, empirical, statistical and future-looking visions of the European academic world have been and shall be a basis for our developing identity.

Prof. Tanel Kerikmäe, Editor-in-Chief

\section{References}

Dixon, P. (n.d.), 'Future of the European Union - Enlarged or Broken?' GlobalChange. com. Retrieved from http://www.globalchange.com/futureeurope.htm [accessed 31 Aug 2015]

Klein, S. (2004), Alles Zufall. Die Kraft, die unser Leben bestimmt, Reinbek: Rowohlt Verlag. 